\title{
Pentingnya Membuat Business Plan pada Startup Aplikasi
}

\author{
Cahya Fajar Ramadhan \\ Program Studi Kewirausahaan \\ Universitas Bina Nusantara \\ cahya.ramadhan@binus.ac.id
}

Salah satu kunci sukses memulai usaha adalah kemampuan menuangkan ide-ide atau gagasan cemerlang yang kreatif dan inovatif dan mempunyai nilai ekonomi atau komersial tinggi ke dalam sebuah Perencanaan bisnis yang matang dan realistis dengan semua jenis usaha yang akan kita jalankan. Kemampuan menuangkan ide-ide tersebut menjadi sebuah tulisan yang dapat dikomunikasikan kepada pihak-pihak lain. Perencanaan bisnis atau business plan adalah rencana-rencana tentang apa yang akan dikerjakan dalam suatu bisnis ke depan, meliputi alokasi sumberdaya, perhatian pada faktor-faktor kunci, mengolah permasalahan-permasalahan dan peluang yang ada.

Hubungan antara startup dan ekonomi kreatif merupakan perumpamaan pada hubungan antara dunia digital dan ekonomi digital. Perkembangan startup menyebabkan hilangnya rahasia diantara manusia. Adanya internet membuat perkembangan dunia semakin pesat dan menyebabkan tidak ada hal yang dapat disembunyikan. Hadirnya startup memberikan dampak pada efektivitas waktu karena kecepatan persebaran informasi. Hal ini dapat dimanfaatkan untuk mendukung industri kreatif yang sedang digalakan, seperti membuat aplikasi dari rumah kerajinan sehingga informasi produk lebih cepat tersebar ke seluruh penjuru negeri tanpa mengeluarkan biaya yang lebih tinggi.

Startup adalah salah satu inkubator bisnis yang berjalan pada UMKM kerajinan sehingga UMKM membutuhkan model pendampingan yang berguna untuk menjalankan usahanya. Ada banyak cara yang dapat dilakukan untuk mengembangkan startup yang bertujuan untuk meningkatkan UMKM di Indonesia dan untuk meningkatkan kreativitas atau inovasi dari para mahasiswa. Perusahaan yang sukses, terdapat inkubator bisnis dan teknologi yang bertujuan untuk memberi pelayanan dalam membina masyarakat berbisnis yang bertujuan agar UMKM terorganisir dengan baik.

Proses inkubasi dalam inkubator bisnis berperan untuk melakukan pendampingan terhadap tenant agar dapat menyelesaikan masalahnya dengan baik sehingga jiwa kompetensi atau bersaing dalam usaha dapat bertahan dan berkembang pesat. Perguruan tinggi merupakan tempat pembelajaran yang baik dalam berwirausaha dengan memberi inovasi untuk dapat membangun usaha sendiri. Peranan perguruan tinggi yang strategis 
perlu diaktifkan untuk mendorong akselerasi perluasan kesempatan kerja melalui pengembangan pelaku-pelaku ekonomi baru seperti entrepreneur yang terampil, yang mempunyai teknologi maju, berusia muda yang produktif-kreatif dan berdaya saing baik di pasar regional maupun di pasar global. Adanya pembelajaran ini, diharapkan tumbuhnya jiwa kompetensi kewirausahaan untuk berani memimpin, mandiri, dan mampu bersaing dengan kreativitas serta inovasi yang dimiliki oleh mahasiswa.

\section{References}

Barringer, B. R. (2015). Preparing Effective Business Plans: An Entrepreneurial Approach (2nd ed.). Pearson Education Limited.

Purnomo, A., Sudirman, A., Hasibuan, A., Sudarso, A., Sahir, S. H., Salmiah, Mastuti, R., Chamidah, D., Koryati, T., \& Simarmata, J. (2020). Dasar-Dasar Kewirausahaan: untuk Perguruan Tinggi dan Dunia Bisnis. Yayasan Kita Menulis.

Lutfiani, N., Rahardja, U., \& Manik, I. S. P. (2020). Peran Inkubator Bisnis dalam Membangun Startup pada Perguruan Tinggi. Jurnal Penelitan Ekonomi Dan Bisnis, 5(1), 77-89. https://doi.org/10.33633/jpeb.v5i1.2727

Supriyanto. (2012). Business Plan sebagai Langkah Awal Memulai Usaha. Jurnal Ekonomi dan Pendidikan, 6(1), 73-83. https://doi.org/10.21831/jep.v6i1.590

Syauqi, A. T. (2016). Startup sebagai Digitalisasi Ekonomi dan Dampaknya bagi Ekonomi Kreatif di Indonesia. Department of Electrical Engineering and Information Technology, 1-4.

\section{Biografi \\ Cahya Fajar Ramadhan}

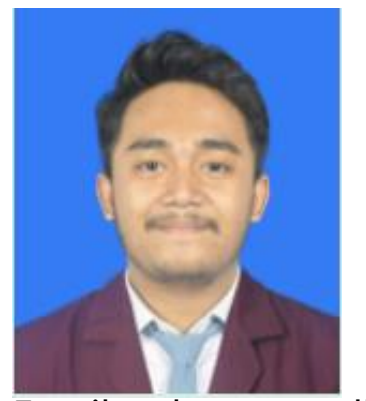

Penulis kelahiran Kota Sidoarjo ini merupakan mahasiswa program studi kewirausahaan di Universitas Bina Nusantara, kampus Malang Angkatan Binusian 2024. Fajar sedang melanjutkan kuliahnya di semester 3 dan sedang menjalankan rintisan wirausaha "Yuk Sehat" yang bergerak di bidang F\&B.

Email: cahya.ramadhan@binus.ac.id Instagram: @cahyafajarr_ 